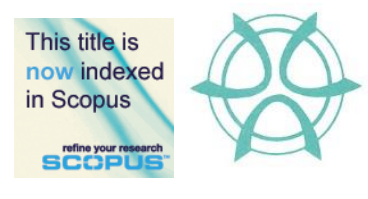

PLANNING MALAYSIA:

Journal of the Malaysian Institute of Planners

VOLUME 15 ISSUE 1 (2017), Page 13 - 20

\title{
CHOOSING AN APPROPRIATE CONTINGENCY SUM ESTIMATING METHODS FOR HIGHWAY CONSTRUCTION PROJECTS IN NIGERIA: A LITERATURE REVIEW
}

\author{
Razali Abdul Hamid', \& Fabi Jonathan Kehinde ${ }^{2}$ \\ ${ }^{1,2}$ Faculty of Built Environment \\ UNIVERSITI TEKNOLOGI MALAYSIA
}

\begin{abstract}
In order to establish a gap to be filled in a particular field, there is a need to gather information that allows the researcher to identify and analyse the current state of researches on the topic. Contingency sum estimation for projects plays an important role for inclusion for risk taken by the contractor on the bid amount. This is good in order to meet project objectives (cost, time, quality, health and safety, and environment). The main function of contingency sum is to cater for variations that arise during the construction phase of projects. The aim of the study is to identifying and examine the various methods for estimating contingency sum for projects with a view to propose an appropriate method which will be suitable for a specific project in order to increase accuracy and reduce cost overrun. A literature review of selected papers (journals, conference proceedings and theses) on contingency estimation was carried out. The major findings from this study is that most studies were carried out on building projects while few were carried out on highway projects. From the analysis carried out, no single method of estimating has been effective for all types of projects. These methods of estimating contingency sums have developed over the years as a result of shortcomings of one method after the other. It is therefore recommended that peculiarity of each project, ease of using each of the methods and accuracy of the estimates needed should be the basis of choosing method of estimating contingency sum.
\end{abstract}

Keywords: Construction projects, contingency sum, estimating, highway

Date Received: $30^{\text {th }}$ April 2016

Date of Acceptance: $30^{\text {th }}$ October 2016 
Razali Abdul Hamid, \& Fabi Jonathan Kehinde

Choosing an Appropriate Contingency Sum Estimating Methods for Highway Construction Projects in Nigeria: A Literature Review

\section{INTRODUCTION}

Cost performance of construction projects is a critical success criterion always watched out for by project sponsors. El-Sayegh and Mansour (2015) state that several studies establish that highway construction projects have higher risks than other construction projects. This is due to the fact that highway projects are capital intensive, take longer time to complete, spread over a wider geographic area and are threatened by underground conditions. Reeley and Brown (2004) posit that infrastructure and underground projects (of which highway projects) are complex and most of the time, span through several terrains, including sandy and rocky areas. Thomas, Kalindidi and Ganesh (2006) cited in El-Sayegh and Mansour (2015) posits that highway projects involve very high risks due to long project duration, low market value of security packages and complex contract mechanisms and involvement of many participants with diverging interest and challenges. The required huge investment and difficult as well as complicated site conditions, according to Zayed, Amer and Pan (2008), make it imperative to have a robust contingency sum which can take care of this imminent risks inherent in highway projects. Cost contingency is included within a budget estimate so that the budget represents the total financial commitment for the project sponsor (Baccarini, 2006). Therefore, choosing an appropriate method of estimating cost contingency and its ultimate adequacy is of great importance to success of projects.

\section{Definition and Attribute of Contingency}

Different researchers such as PMI (2000) have at different times offer varying definitions of contingency. AACE (2010) defines contingency as "an amount added to an estimate to allow for items, conditions, or events for which the state, occurrence, or effects is uncertain and that experience shows will likely result, in aggregate, in additional costs". Bakshi and Touran (2014) offer a definition of cost contingency which is very relevant for this study, as a reserved budget for coping with monetary impacts of risks and uncertainties associated with a project. However, AACE (2010) states that contingency does not cover the following: (i) major scope changes (ii) extraordinary events such as major strike and catastrophes (iii) escalation and currency effect and (iv) management reserves.

Besides, many researchers applied the extension rule to the model counting problem (Touran, 2003), and many amended it so as to apply it into the TP of modal logic19. Still some researchers improved the extension rule, and put forward series of algorithms such as NER, RIER, etc (Yeo, 1990; Zayed, Amer \& Pan, 2008).

Extension-rule based TP method has commended considerable respect from many related researchers. For example, Murray (PMI, 2000; Thomas, Kalindidi \& Ganesh, 2006) has applied the extension rule into the generation of the target language based on the knowledge compilation, and 
achieved good results. Besides, many researchers applied the extension rule to the model counting problem (Touran, 2003), and many amended it so as to apply it into the TP of modal logic (Touran \& Liu, 2015). Still some researchers improved the extension rule, and put forward series of algorithms such as NER, RIER, etc (Yeo, 1990; Zayed, Amer \& Pan, 2008).

\section{RESEARCH METHODOLOGY}

This study is a theoretical research based on review of literature on the methods of estimating cost contingency for construction projects. Academic journals, conference proceedings, textbooks, monograms and other valuable materials that are relevant to the study were selected and referenced. The study carried out a comprehensive survey of literature to highlight the findings of previous researchers with the view to examine the characteristics of different contingency estimation methods, in order to choose an appropriate method when the need arises so as to provide an adequate and reliable contingency sum for construction projects.

\section{CRITICAL ANALYSIS ON VARIOUS METHODS OF ESTIMATING COST CONTINGENCY}

\begin{tabular}{|c|c|c|c|c|c|}
\hline $\mathbf{S} / \mathbf{N}$ & Methods & Researchers & $\begin{array}{l}\text { Advantages } \\
\text { of the } \\
\text { Methods } \\
\end{array}$ & $\begin{array}{l}\text { Disadvantages } \\
\text { of the Methods }\end{array}$ & $\begin{array}{l}\text { Projects } \\
\text { used for }\end{array}$ \\
\hline 1. & $\begin{array}{l}\text { Traditional } \\
\text { method }\end{array}$ & $\begin{array}{l}\text { Ahmed, 1992; } \\
\text { Molsehi, 1997; } \\
\text { Baccarini, } \\
\text { 2004; } \\
\text { Mohammed, } \\
\text { 2009; Adama } \\
\text { \& Jimoh, } \\
\text { 2014; Amade } \\
\text { et al., 2014. }\end{array}$ & $\begin{array}{l}\text { It is easy to } \\
\text { use. It does } \\
\text { not require } \\
\text { long time or } \\
\text { budget. }\end{array}$ & $\begin{array}{l}\text { Risk is either } \\
\text { ignored or dealt } \\
\text { with in arbitrary } \\
\text { way. Not suitable } \\
\text { for big projects. } \\
\text { Fail to take risk } \\
\text { drivers in to } \\
\text { consideration. } \\
\text { No justification } \\
\text { for the } \\
\text { percentage used. }\end{array}$ & $\begin{array}{l}\text { All form of } \\
\text { construction } \\
\text { projects. } \\
\text { Developing } \\
\text { countries } \\
\text { still adopt it } \\
\text { for highway } \\
\text { projects, } \\
\text { especially } \\
\text { Nigeria. }\end{array}$ \\
\hline 2. & $\begin{array}{l}\text { Individual } \\
\text { risk - } \\
\text { Expected } \\
\text { Value }\end{array}$ & $\begin{array}{l}\text { Mak, Wong \& } \\
\text { Picken, } 2000 .\end{array}$ & $\begin{array}{l}\text { It can model } \\
\text { uncertainty } \\
\text { as } \\
\text { contingencies } \\
\text { with specific } \\
\text { probabilities } \\
\text { which can be } \\
\text { analysed for } \\
\text { better result. }\end{array}$ & $\begin{array}{l}\text { Identifying fixed } \\
\text { and variable } \\
\text { factors of the } \\
\text { projects is } \\
\text { difficult. It still } \\
\text { adopts traditional } \\
\text { approach. }\end{array}$ & $\begin{array}{l}\text { Construction } \\
\text { projects } \\
\text { generally. }\end{array}$ \\
\hline 3. & $\begin{array}{l}\text { Method of } \\
\text { Moment }\end{array}$ & $\begin{array}{l}\text { Diekmann, } \\
\text { 1983; Yeo, }\end{array}$ & $\begin{array}{l}\text { This method } \\
\text { is good in } \\
\text { situation }\end{array}$ & $\begin{array}{l}\text { Due to its } \\
\text { mathematical } \\
\text { background, it is }\end{array}$ & $\begin{array}{l}\text { Rarely used } \\
\text { in practice. }\end{array}$ \\
\hline
\end{tabular}


Razali Abdul Hamid, \& Fabi Jonathan Kehinde

Choosing an Appropriate Contingency Sum Estimating Methods for Highway Construction Projects in Nigeria: A Literature Review

\begin{tabular}{|c|c|c|c|c|c|}
\hline & & $\begin{array}{l}\text { 1990; Molsehi, } \\
\text { 1997. }\end{array}$ & $\begin{array}{l}\text { where } \\
\text { simulation is } \\
\text { inefficient. } \\
\text { No need to } \\
\text { invest in any } \\
\text { software. }\end{array}$ & $\begin{array}{l}\text { very difficult to } \\
\text { use. Not suitable } \\
\text { for complex and } \\
\text { large } \\
\text { infrastructure. }\end{array}$ & \\
\hline 4. & $\begin{array}{l}\text { Monte } \\
\text { Carlo } \\
\text { Simulation }\end{array}$ & $\begin{array}{l}\text { Lorance \& } \\
\text { Wendling, } \\
\text { 1999; Clark, } \\
\text { 2001; Barazza } \\
\text { \& Bueno, } \\
2007 .\end{array}$ & $\begin{array}{l}\text { It captures } \\
\text { outcome of } \\
\text { risk } \\
\text { identification } \\
\text { and impact } \\
\text { which can be } \\
\text { used to } \\
\text { estimate } \\
\text { contingency. }\end{array}$ & $\begin{array}{l}\text { The method is } \\
\text { hard and } \\
\text { cumbersome. It } \\
\text { is rarely used in } \\
\text { the industry. } \\
\text { Only good when } \\
\text { there linear } \\
\text { relationship } \\
\text { between project } \\
\text { parameters. }\end{array}$ & $\begin{array}{l}\text { Heavy } \\
\text { capital } \\
\text { projects }\end{array}$ \\
\hline 5. & $\begin{array}{l}\text { Regression } \\
\text { Analysis }\end{array}$ & $\begin{array}{l}\text { Merrow \& } \\
\text { Yarossi, 1990; } \\
\text { Aibinu \& } \\
\text { Jagboro, 2002; } \\
\text { Sonmez, 2004; } \\
\text { Thai, Cook \& } \\
\text { White, 2010; } \\
\text { Kim et al., } \\
\text { 2004; Bello \& } \\
\text { Odusami, } \\
\text { 2013; } \\
\text { Abednego et } \\
\text { al. 2014. }\end{array}$ & $\begin{array}{l}\text { It addresses } \\
\text { the factors } \\
\text { that drive } \\
\text { project risk. } \\
\text { It is more } \\
\text { accurate than } \\
\text { traditional } \\
\text { method. }\end{array}$ & $\begin{array}{l}\text { It relies on } \\
\text { historical cost } \\
\text { data which } \\
\text { sometimes may } \\
\text { not be available. } \\
\text { Time consuming } \\
\text { to gather } \\
\text { historical cost } \\
\text { data. }\end{array}$ & $\begin{array}{l}\text { All } \\
\text { construction } \\
\text { projects, but } \\
\text { majorly on } \\
\text { building } \\
\text { projects. }\end{array}$ \\
\hline 6 & $\begin{array}{l}\text { Range } \\
\text { Estimating }\end{array}$ & Curran, 1989. & $\begin{array}{l}\text { It takes care } \\
\text { of optimistic } \\
\text { and } \\
\text { pessimistic } \\
\text { ends of } \\
\text { estimation. It } \\
\text { is safer than } \\
\text { the } \\
\text { traditional } \\
\text { method. }\end{array}$ & $\begin{array}{l}\text { It also adopts } \\
\text { deterministic } \\
\text { approach which } \\
\text { makes it less } \\
\text { accurate compare } \\
\text { to regression } \\
\text { models. }\end{array}$ & $\begin{array}{l}\text { Roads in } \\
\text { WISDOT }\end{array}$ \\
\hline 7. & $\begin{array}{l}\text { Artificial } \\
\text { Neural } \\
\text { Networks }\end{array}$ & $\begin{array}{l}\text { Chen \& } \\
\text { Hartman, } \\
\text { 2000; } \\
\text { Williams, } \\
\text { 2003; Cook, } \\
\text { 2006; Polat, } \\
\text { 2012. } \\
\end{array}$ & $\begin{array}{l}\text { Prediction } \\
\text { accuracy of } \\
\text { ANNs gives } \\
\text { better results } \\
\text { than } \\
\text { traditional } \\
\text { method } \\
\end{array}$ & $\begin{array}{l}\text { ANN is suitable } \\
\text { for non-linear } \\
\text { modelling of } \\
\text { data. }\end{array}$ & $\begin{array}{l}\text { Roads, Oil } \\
\text { and gas } \\
\text { projects }\end{array}$ \\
\hline 8 & $\begin{array}{l}\text { Factor } \\
\text { Rating }\end{array}$ & $\begin{array}{l}\text { Hackney, } \\
1985 ;\end{array}$ & $\begin{array}{l}\text { This method } \\
\text { can be used }\end{array}$ & $\begin{array}{l}\text { Choosing the } \\
\text { four }\end{array}$ & $\begin{array}{l}\text { Capital } \\
\text { project in the }\end{array}$ \\
\hline
\end{tabular}


PLANNING MALAYSIA

Journal of the Malaysia Institute of Planners (2017)

\begin{tabular}{|c|c|c|c|c|c|}
\hline & $\begin{array}{l}\text { /Estimate } \\
\text { Quality }\end{array}$ & $\begin{array}{l}\text { Oberlander \& } \\
\text { Trost, } 2001 .\end{array}$ & $\begin{array}{l}\text { to check the } \\
\text { amount of } \\
\text { contingency } \\
\text { determined } \\
\text { by other } \\
\text { methods of } \\
\text { estimating } \\
\text { contingency } \\
\text { sum, apart } \\
\text { from being a } \\
\text { method of } \\
\text { estimating } \\
\text { contingency. }\end{array}$ & $\begin{array}{l}\text { determinants of } \\
\text { the accuracy of } \\
\text { the estimate is } \\
\text { severely } \\
\text { inadequate. It } \\
\text { may lead to high } \\
\text { contingency if } \\
\text { the estimate is } \\
\text { inaccurate. }\end{array}$ & $\begin{array}{l}\text { Process } \\
\text { industry. }\end{array}$ \\
\hline 9 & $\begin{array}{l}\text { Influence } \\
\text { Diagram }\end{array}$ & $\begin{array}{l}\text { Diekmann \& } \\
\text { Featherman, } \\
\text { 1998; Park et } \\
\text { al., 1998; } \\
\text { Oppong, } 2013 .\end{array}$ & $\begin{array}{l}\text { It reduces } \\
\text { large } \\
\text { volumes of } \\
\text { data crucial } \\
\text { for making } \\
\text { decision. } \\
\text { Good in } \\
\text { sensitivity } \\
\text { analysis. }\end{array}$ & $\begin{array}{l}\text { Like other } \\
\text { probability } \\
\text { models, }\end{array}$ & $\begin{array}{l}\text { Complex } \\
\text { construction } \\
\text { projects. }\end{array}$ \\
\hline 10. & $\begin{array}{l}\text { Theory of } \\
\text { Constraints }\end{array}$ & Leach, 2003. & $\begin{array}{l}\text { It makes use } \\
\text { of three point } \\
\text { estimates and } \\
\text { with the use } \\
\text { of probability } \\
\text { function } \\
\text { makes it } \\
\text { more } \\
\text { accurate than } \\
\text { the } \\
\text { traditional } \\
\text { method. }\end{array}$ & $\begin{array}{l}\text { This method } \\
\text { assumes cost } \\
\text { items are } \\
\text { independent of } \\
\text { each other which } \\
\text { is not true in real } \\
\text { in real life. }\end{array}$ & $\begin{array}{l}\text { All form of } \\
\text { construction } \\
\text { projects }\end{array}$ \\
\hline 11. & Fuzzy Sets & $\begin{array}{l}\text { Paek, Lee \& } \\
\text { Ock, 1993; } \\
\text { Shayen, Fayek } \\
\text { \& Aburizk, } \\
\text { 2007; } \\
\text { Rezakhani, } \\
2012 .\end{array}$ & $\begin{array}{l}\text { It allows } \\
\text { analysis with } \\
\text { small } \\
\text { samples. It } \\
\text { reveals } \\
\text { relationship } \\
\text { between } \\
\text { outcome and } \\
\text { explanatory } \\
\text { variables. }\end{array}$ & $\begin{array}{l}\text { It is hard to } \\
\text { develop a fuzzy } \\
\text { model. It } \\
\text { requires more } \\
\text { fine-tuning } \\
\text { which has made } \\
\text { it difficult in real } \\
\text { practice. }\end{array}$ & $\begin{array}{l}\text { Majorly on } \\
\text { building } \\
\text { projects but } \\
\text { in few } \\
\text { occasions for } \\
\text { highway } \\
\text { projects. }\end{array}$ \\
\hline 12. & $\begin{array}{l}\text { Analytical } \\
\text { Hierarchy } \\
\text { Process }\end{array}$ & $\begin{array}{l}\text { Dey, } \\
\text { Tabucanon \& } \\
\text { Ogunlana, } \\
\text { 1994; El- } \\
\text { Touny, }\end{array}$ & $\begin{array}{l}\text { AHP is good } \\
\text { in solving } \\
\text { complex } \\
\text { estimating } \\
\text { and decision }\end{array}$ & $\begin{array}{l}\text { It cannot be used } \\
\text { to find a true } \\
\text { solution to a } \\
\text { problem or }\end{array}$ & $\begin{array}{l}\text { Complex } \\
\text { construction } \\
\text { like civil and } \\
\text { heavy }\end{array}$ \\
\hline
\end{tabular}


Razali Abdul Hamid, \& Fabi Jonathan Kehinde

Choosing an Appropriate Contingency Sum Estimating Methods for Highway Construction Projects in Nigeria: A Literature Review

\begin{tabular}{|l|l|l|l|l|l|}
\hline & & $\begin{array}{l}\text { Ibrahim \& } \\
\text { Amer, 2014. }\end{array}$ & $\begin{array}{l}\text { making } \\
\text { problems } \\
\text { which } \\
\text { characterizes } \\
\text { construction } \\
\text { projects. }\end{array}$ & $\begin{array}{l}\text { deriving a final } \\
\text { answer. }\end{array}$ & $\begin{array}{l}\text { engineering } \\
\text { projects. }\end{array}$ \\
\hline 13. & $\begin{array}{l}\text { Bayesian } \\
\text { Belief } \\
\text { Network. }\end{array}$ & $\begin{array}{l}\text { Khallafah, } \\
\text { Taha \& El- } \\
\text { Said, 2002. }\end{array}$ & $\begin{array}{l}\text { This method } \\
\text { uses } \\
\text { probability } \\
\text { method } \\
\text { which is } \\
\text { more } \\
\text { accurate than } \\
\text { the } \\
\text { traditional } \\
\text { method. }\end{array}$ & $\begin{array}{l}\text { It is difficult to } \\
\text { use by layman }\end{array}$ & $\begin{array}{l}\text { Residential } \\
\text { buildings. }\end{array}$ \\
\end{tabular}

With the extant review of literature, the major findings in the analysis of different contingency sum estimation methods are:

1) Traditional percentage method has been widely used across all projects despite criticisms that it is based on intuition and no rationale for arriving at the percentage. Regression and Theory of constraints have also been used in estimating contingency sum for construction projects

2) Monte Carlo Simulation, ANN, Influence Diagram and AHP have been used for complex projects such as heavy engineering, roads, oil and gas. These methods give high degree of accuracy.

3) While Bayesian Belief method has been widely used for residential buildings, method of moment is rarely used in practice.

4) Range estimating has been used in estimating contingency sum in WISDOT.

5) Factor rating/ Estimate quality has been used to estimate contingency sum for capital projects in the process industry.

\section{CONCLUSION}

This study reviews the concept of contingency estimation for construction projects with a special emphasis on highway projects. While so many researchers have focused on building projects, little attention has been paid to estimating contingency sum for highway projects which have higher risks than other construction projects. From the analysis carried out, no single method of estimating has been effective for all types of projects. These methods of estimating contingency sums have developed over the years as a result of shortcomings of one method after the other. Also, this study will guide practitioners in the industry on which method to use, having considered the 
advantages, disadvantages and type of projects different methods have been used. It is therefore recommended that peculiarity of each project, ease of using each of the methods and accuracy of the estimates needed should be the basis of choosing method of estimating contingency sum

\section{REFERENCES}

Adama, S. M., \& Jimoh, R. A. (2014). Assessment of contingency sum in relation to the total cost of renovation work in public school in Abuja, Nigeria.

Amade, B., Akpan, E. O. P., Ukwuoma F. P. O., \& Alajemba C. C. (2014). Project cost contingency in the Nigerian construction industry. International Journal of Research in Management Science and Technology, 2(2), 9-21.

Association for the Advancement of Cost Engineering (AACE) (2010). International. Cost Engineering Terminology. AACE Recommended Practice No. 10-90, TCM Framework: General Reference, March 5.

Baccarini D. (2004). Accuracy in estimating project cost construction contingency - a statistical analysis. In E. Robert \& B. Malcolm (Eds.), Proceeding of the Construction and Building Research Conference of RICS, 7-8 September, 2004.

Baccarini D. (2006). The maturing concept of estimating project cost contingency - a review. 31st Australia University Build Education Assessment Conference. (AUBEA 2006), Curtis University of Technology, Australia.

Bakhshi, P., \& Touran, A. (2014). An overview of budget contingency calculation methods in construction industry. Procedia Engineering, 85, 52-60.

Bello, W. A., \& Odusami, K.T. (2013). Weak management of the predictability of contingency allowance in construction projects in Nigeria. In S.D. Smith \& D.D. Ahiaga-Dagbui (Eds.), Proceeding of the 29th Annual ARCOM Conference (pp. 969-978), 2-4 September. Reading, UK.

Buertey, J. I. T., Abeere-Inga, F., \& Kumi, T. A. (2012). Practical application of risk management techniques in infrastructural delivery: a case study of Ghanaian construction industry. Journal of Construction Project Management and Innovation, 2(1), 224-244.

CIRIA (Construction Industry Research and Information Association) (1996). Control of risk: a guide to the systematic management of risk from construction. London: CIRIA.

Dey, P., Tabucanon, M. T., \& Ogunlana S. (1994). Planning for project control through risk analysis: a petroleum pipeline-laying project. International Journal of Project Management. 12(1), 23-33.

El-Sayegh, S., \& Mansour, M., (2015). Risk assessment and allocation in highway construction projects in the UAE. Journal Management Engineering, 31(6).

El-Touny, A. S., Ibrahim, A. H., \& Amer, M. I. (2014). Estimating contingency for highway projects using analytical hierarchy processes. International Journal of Computer Science, 11(6), No. 1.

Mak, S., Wong, J., \& Picken, D. (1998). The effect on contingency allowances of using risk analysis in capital cost estimating: a Hong Kong case study. Journal Construction Management and Economics, 16, 615-619. 
Molsehi, O. (1997). Risk assessment and contingency estimating. In Association for the Advancement of Cost Engineering (AACE), Inter. Transaction, D\&RM/A.06.

Otali, M., \& Odesola, I. A. (2014). Effectiveness evaluation of contingency sum as a risk management tool for construction projects in Niger-Delta, Nigeria. Ethiop. Journal of Environment Standard and Management. 7(6), 588-598.

PMI [Project Management Institute] (2000). A guide to the project management body of knowledge. Upper Darby PA: PMI.

Thomas, A.V., Kalindidi, S. N., \& Ganesh, L. S. (2006). Modelling and assessment of critical risk in BOT road projects. Journal of Construction Management and Economics, 24, 407-424.

Thompson, P.A., \& Perry, J. G. (1992). Engineering construction risk: a guide to project risk analysis and risk management. London: Thomas Telford.

Touran, A. (2003). Calculating contingency in construction projects. Journal of English Management, IEE Trans, 50(2)135-14.

Touran, A., \& Liu, J. (2015). A method for estimating contingency based on project complexity. Procedia Engineering, 123, 574- 588.

Yeo, K. T. (1990). Risks, classification of estimates and contingency management. Journal of Management in Engineering, 6(4), 458-470.

Zayed, T., Amer, M., \& Pan, J., (2008). Assessing risk and uncertainty inherent in Chinese highway projects using AHP. International Journal of Management, 26(4), 408-419. 


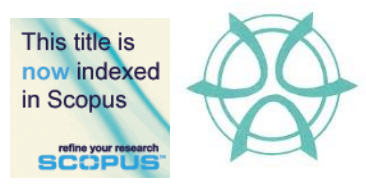

PLANNING MALAYSIA:

Journal of the Malaysian Institute of Planners

VOLUME 15 ISSUE 1 (2017), Page 21 - 30

\title{
A THEORETICAL ASSESSMENT ON SUSTAINABLE WELLBEING INDICATORS FOR PEOPLE INTERRELATIONSHIPS
}

\author{
Aisyah Abu Bakar', Mariana Mohamed Osman², Syahriah Bachok ${ }^{3}$, Ismawi Zen ${ }^{4}$, \\ Alias Abdullah ${ }^{5}$, \& Muhammad Faris Abdullah ${ }^{6}$ \\ 1,2,3,4,5,6 Kulliyyah of Architecture and Environmental Design, \\ INTERNATIONAL ISLAMIC UNIVERSITY MALAYSIA
}

\begin{abstract}
Sustainable well-being is the well-being attained without compromising others' opportunities to pursue their happiness. The concept of well-being is not merely personal, relational, organizational or communal issues, but rather the synergy of all four dimensions. The four dimensions of well-being are distinguishable, but they are inseparable entities. While focusing on subjective measure of well-being some research fail to interrogate the influence of contextual dynamics on respondents who report high levels of well-being despite living in deprived community conditions. This study argues that there could not be well-being without the combination of personal, relational, organizational and communal wellness.
\end{abstract}

Keyword: sustainable well-being, human interrelationships with other humans.

Date Received: $30^{\text {th }}$ April 2016

Date of Acceptance: $30^{\text {th }}$ October 2016 